\title{
Consequence of Regional Trade Agreements to Developing Countries
}

\author{
Craig R. MacPhee \\ Department of Economics, University of Nebraska-Lincoln, Lincoln, Nebraska, U.S.A. \\ Wanasin Sattayanuwat \\ School of Economics and Public Policy, Srinakharinwirot University, Bangkok, Thailand
}

\begin{abstract}
We investigate the effects of 12 major Regional Trade Agreements (RTAs) on intraand extra-regional trade flows in member developing countries, both intra-RTA trade and the effect of RTAs on non-member trade over 1981 2008. We address and resolve statistical problems caused by logarithms, zero observations, and heteroskedasticity. Our regression results are not favorable to regional integration as a substitute for multilateral trade liberalization, although there are exceptions. Several RTAs fail to generate intrabloc trade creation. Seven of the 12 RTAs generate import trade diversion while most of the extra-bloc export dummies are not statistically significant. However, three of the five African RTAs in the sample increased intra-bloc trade. The differences in RTA performances are related to their implementation policies.
\end{abstract}

JEL Classifications: F15, O19, O57

Key words: : Regional Trade Agreements, Gravity Models, Developing Countries

\footnotetext{
* Corresponding Author: Craig R. MacPhee; Department of Economics, University of Nebraska-Lincoln, Lincoln, NE 68588-0489, U. S. A.; Tel: +1 4024836594, Fax: +1 4024729700, E-mail: cmacphee@unl.edu.

Co-Author: Wanasin Sattayanuwat; School of Economics and Public Policy, Srinakharinwirot University, 114 Sukhumvit23, Bangkok 10110 Thailand; Tel: +662 1691004, Fax:+662 1691005, E-mail: wanasin@gmail.com.
} 


\section{Introduction}

At the beginning of the $1990 \mathrm{~s}$, the WTO recognized 40 discriminatory trade arrangements among member countries, arrangements that were considered exceptions to the Most Favored Nation(MFN) principle. Twenty years later, the exception has become the rule as the number of discriminatory arrangements has grown up to $202^{1}$. Of these 202 arrangements reported to the WTO, 109 are bilateral agreements; 57 are agreements between a country and a regional grouping or two such groupings with each other; and 36 are pure Regional Trade Agreements (RTAs).

This study investigates the performance of the main RTAs in developing countries using new techniques with a longer data set, from 1981 to 2008 . We estimate the trade effects from 12 major developing-country RTAs simultaneously. We also provide estimates for several RTAs ignored in previous studies using internal-external tradecreation-diversion models.

Ever since Viner's (1951) pioneering work on customs unions, it has been recognized that RTAs could enhance welfare through trade creation and reduce welfare through trade diversion. Viner noted that the size of these welfare effects depended on market structure variables such as the elasticities of demand and supply, the geographical proximity of RTA members, and the relative number of substitute products produced by RTA members. However, Viner also pointed out that RTA policies could have an important influence on trade creation and diversion. Allowing more countries to become members of an RTA, and reducing external RTA tariffs on imports from non-member states were two important policies would enhance trade creation and improvements in welfare.

In recent years, additional policies to promote trade creation have been suggested. The World Bank (2006) advocates eliminating intra-RTA tariffs for all products across the board, establishing RTA dispute settlement systems, and simplifying and harmonizing rules of origin. Liberalization of foreign investment and migration are policies that can promote trade creation and lessen trade diversion, and many RTAs now include provisions related to investment and migration. Finally, there has been concern that RTAs would become a substitute for multilateral liberalization. If this

\footnotetext{
1 (Updated October 2010) This number counts only RTAs and not the number of members. The EC treaty, for instance, was started in 1957 and enlarged to 9 members in 1972, and enlarged to 10 members, 12 members, 15 members, 25 members, and 27 members in 1979, 1985, 1994, 2004 and 2006 respectively. The total number of RTA in the WTO record is 225.
} 
takes place, increased protection of vested interests could turn the agreements into closed blocs, discouraging multilateralism, and distorting the pattern of international trade (Tumbarello, 2007).

Whether RTAs are complements to or substitutes for multilateral free trade is a subject of ongoing debate. One school of thought views RTAs as reducing global welfare and creating stumbling blocks to multilateral free trade (Bhagwati and Krueger, 1995; Bhagwati and Panagariya, 1996; Srinivasan, 1998). Another school of thought argues that RTAs are likely to raise global welfare and to act as building blocks to multilateral free trade (Ethier, 1998; Schott, 2004). This can be viewed as two sides of the same coin. On the one hand, RTAs undermine progress toward the global trade liberalization. On the other hand, any trade liberalization is good whatever its source and RTAs act as a second-best means of achieving trade liberalization when multilateral progress is delayed. Another viewpoint in the RTA debate sees natural trading blocs among neighboring countries because of low transportation costs that contribute to welfare gains (Krugman, 1993). Finally, there are concerns about the proliferation of RTAs leading to a costly hub-and-spoke structure of trade ${ }^{2}$ and a spaghetti bowl phenomenon $^{3}$.

An important first step is to assess the trade effects of RTAs. This study focuses on intra- and extra-regional trade flows before and after the RTA implementations. We consider not only intra-RTA trade but also the effect of RTAs on non-member trade. Our results suggest that regional arrangements among developing countries generally have been a poor substitute for multilateral trade liberalization although there are some exceptions. As we review our statistical results for each RTA below, we briefly discuss policy problems associated with the implementation of trade preferences.

Ideally, all RTAs should be included in the analysis, but computational limitations allow us to study only large developing RTAs ${ }^{4}$. In this study, we focus on the 12 major

\footnotetext{
${ }^{2}$ Such a structure can emerge when the largest RTA member (hub) signs individual agreements with a wide range of peripheral countries (spokes), among which market access remains restricted. Such arrangements can marginalize the spokes, where market access conditions are less advantageous than in the hub, which enjoys improved access to all of the spokes. Such a game may generate lower gains among the spoke members, which instead accrues mainly to the hub country (Deltas, Desmet, \& Facchini, 2006).

3 The term 'spaghetti bowl phenomenon' was first used by Jagdish Bhagwati in "U.S. Trade Policy: The Infatuation with Free Trade Agreements" in Jagdish Bhagwati and Anne O. Krueger, The Dangerous Drift to Preferential Trade Agreements, AEI Press, 1995. This term refers to the potential problems arising from a lack of coherence among different overlapping agreements. There has been little effort toward regulatory harmonization and consistency among agreements. As a result, restrictive and inconsistent rules of origin across agreements can complicate outsourcing decisions by firms and add fragility to trading systems. Furthermore, the outcome of a trade dispute between two members has the potential to spill over to other countries in regional trade relations. In the absence of a regional dispute settlement mechanism, there is a potential risk of disruption in intra-regional trade (Tumbarello, 2007).

${ }^{4}$ Hamilton and Winters (1992) have observed that many small RTAs made up of low and middle income countries have little effect on world trade flows.
} 
developing-country RTAs as shown in Table 1. Individual member countries from each region of the world are listed in Table A1. of the Appendix.

\section{Table 1. Selected RTAs in Developing Countries}

\begin{tabular}{l|l|c|l}
\hline \multicolumn{1}{c|}{ Agreement } & Type & \multicolumn{1}{c}{ Region } \\
\hline AFTA & ASEAN Free Trade Area & FTA & South East Asia \\
CAN & Andean Community & CU & Western Hemisphere \\
CEMAC & Economic and Monetary Community of Central Africa & CU & Sub-Saharan African \\
CIS & Commonwealth of Independent States & FTA & Europe and Central Asian \\
EAC & East African Community & CU & Sub-Saharan African \\
ECOWAS & Economic Community of West Africa & CU & Sub-Saharan African \\
GCC & Gulf Cooperation Council & CU & Middle East \\
MERCOSUR & Southern Common Market & CU\&EIA & Western Hemisphere \\
PAFTA & Pan-Arab Free Trade Area & FTA & Middle East \& North Africa \\
SADC & Southern African Development Community & FTA & Sub-Saharan African \\
SAPTA & Southern Asian Preferential Trade Arrangement & PTA & South Asia \\
WAEMU & West African Economic and Monetary Union & CU & Sub-Saharan African \\
\hline
\end{tabular}

(Source) WTO.

The study is organized as follows. First, we provide a review of RTA research. Second, we describe the gravity models used to estimate the impact of RTAs with the econometric issues involved. Finally, we discuss the results for each RTA, including some comments on policies that have promoted trade creation over trade diversion.

\section{Literature Review}

The welfare effects of RTAs were first assessed by Viner (1951) in terms of trade creation and trade diversion. Trade creation takes place when the imports and exports of members within a preferential arrangement expand due to the elimination of internal trade barriers. Trade diversion occurs when trade shifts from outside trading partners to members of the preferential arrangement. With trade diversion, a product that is 
available at a relatively low price from a more efficient outsider is imported from an RTA partner at a higher cost and sold at a higher price. Trade diversion induces inefficient production within the arrangement and prevents consumer surplus from rising to multilateral free trade levels. The balance between trade diversion and trade creation is one of the key elements determining the net welfare effects of a preferential arrangement (Rivera-Batiz and Oliva, 2003).

Empirical assessments of the effects of RTAs fall into two categories: ex post and ex ante. Ex ante analyses are usually based on computable general equilibrium models (CGE) and are used to predict the effects of an RTA before it is formed. Assessments of resource allocation effects and welfare changes are based on estimated parameters and data corresponding to the period preceding the formation of the RTA. Ex post analyses utilize data available both before and after the RTA has been formed. These studies often focus on the effect of RTAs on the trade shares of members and nonmembers (Rivera-Batiz and Oliva, 2003).

Each empirical approach has inherent weaknesses. CGE analyses suffer from a number of theoretical and practical difficulties such as assuming fixed terms of trade, assuming many elasticities of substitution, comprehensive elimination of tariffs, and ignoring many potentially trade-restrictive non-tariff measures. Ex post studies, on the other hand, do not estimate welfare effects directly (Dee and Gali, 2005) and are subject to several econometric problems. The gravity model is the key ex post technique for evaluation of the effects of RTAs and we utilize it in this study.

\section{Gravity Model}

The first extended use of regional dummy to capture an RTA's effect on intraregional trade was done by Aitken (1973). Later Bayoumi and Eichengreen (1995) and Frankel (1997) added a second dummy to test the RTA effect on the trade of bloc members with nonmembers. Recently Soloaga and Winters (2001) incorporated three dummy variables in order to offer a simple and clear distinction between trade creation and trade diversion. The first dummy captures trade creation, while the second and the third dummy variables capture import trade diversion and the export trade diversion, respectively. They argued that both are needed because bloc member's imports and exports could follow different patterns after the formation of an RTA. 
Here we follow the specification of Soloaga and Winters (2001) who use separate dummies for member's imports from nonmembers and their exports to nonmembers.

Equation (1) is a gravity model explaining bilateral trade flows with GDP, population, language, distance, adjacency, real exchange rate, and trade policy variables.

$$
\begin{aligned}
& X_{i j t}=f\left(Y_{i t}, Y_{j t}, N_{i t}, N_{j t}, L A N G_{i j}, A D J_{i j}, D I S_{i j}, R E R_{i j t}\right. \text {, } \\
& \left.T_{A F} F_{i j t}, R T A 2 k_{i j t}, \text { RTAkimp }_{i j t}, \text { RTAkexp }_{i j t}\right)
\end{aligned}
$$

where

$X_{i j t}$ is the value of exports ${ }^{5}$ from country $i$ to country $j$ in year $t$,

$Y_{j t}$ is the gross domestic product of country $j$ in year $t$,

$Y_{i t}$ is the gross domestic product of country $i$ in year $t$,

$N_{j t}$ is the population size of country $j$ in year $t$,

$N_{i t}$ is the population size of country $i$ in year $t$,

$L A N G_{i j}$ is a dummy variable indicating that country $i$ and country $j$ have a common language,

$A G J_{i j}$ is a dummy variable indicating that country $i$ and country $j$ have a common border,

$D I S_{i j}$ is the distance between country $i$ and country $j$,

$R E R_{i j t}$ is the real exchange rate between country $i$ and country $j$ in year $t$,

$R T A 2_{i j t}$ is a dummy variable indicating that country $i$ and $j$ are members of the same RTA $k$ in year $t$. This variable indicates intra-bloc trade for each RTA under consideration. A positive coefficient for this variable indicates that the intra-bloc trade would be greater.

RTAkimp $_{i j t}$ is a dummy variable for country $i$ that is not member of the group $k$ of which country $j$ is a member in year $t$. This variable indicates extra-bloc imports of the member countries of regional groups. A negative coefficient for this variable indicates that member countries are importing less from non-members. The literature refers to

\footnotetext{
${ }^{5}$ Many gravity models estimate RTA effects using total bilateral trade flows as a dependent variable. However for a given pair of countries, with total bilateral trade one cannot distinguish between the impacts of RTA formation on exports from a non-member to RTA members from that on exports from an RTA member to a non-member. Therefore, a constant level for overall bilateral trade (exports and imports) may be the result of a reduction in imports from non-members and an increase in exports from RTA-members to third countries. Therefore, using bilateral exports instead of total bilateral trade is crucial for the construction of a meaningful RT Akimp dummy and dummy (Cernat , 2001). In addition import data might be contaminated by the noise component of trade costs affected by movements in oil prices, whereas export data are free of the volatility induced by transportation costs, thus giving us a clearer picture of global trade (Croce, Juan-Ramon, \& Zhu, 2004).
} 
this effect as 'Import Trade Diversion (MTD).'

RTAkexp $_{i j t}$ is a dummy variable indicating that country $i$ is a member of the group $k$ of which country $j$ is not a member in year $t$. This variable indicates extra-bloc exports of the member countries of regional groups. A negative coefficient for this variable indicates that the RTA has resulted in the member countries exporting less to nonmembers. This effect is referred to as 'Export Trade Diversion (XTD).' RTA dummies are assigned the value of one as of the date of a country's entry into the RTA'. The three RTA variables allow us to determine the trade creation and diversion effects imputable to the various country groups and to see if they constitute building blocks or stumbling blocks to economic progress. In assessing our results, we use a typology of trade creation and diversion drawn up by Trotignon (2010). Interpretation of the three coefficients with this typology is summarized in Tables 2 and 3.

\section{Table 2. Typology of Trade Creation and Diversion}

\begin{tabular}{|l|l|}
\hline Designation & Effect of Regional Grouping \\
\hline Intra-bloc Trade Creation (ITC) & Stimulating effect on trade between partners \\
\hline Export Trade Creation (XTC) & Stimulating effect on exports to the rest of the world \\
\hline Import Trade Creation (MTC) & Stimulating effect on imports from the rest of the world \\
\hline Import Trade Diversion (MTD) & Imports from the rest of the world are replaced by intra-bloc trade \\
\hline Export Trade Diversion (XTD) & Exports to the rest of the world are replaced by intra-bloc trade \\
\hline
\end{tabular}

(Source) Trotignon (2010), Table 3, p.241

Table 2 relates the designation of each type of creation and diversion to the corresponding trade effects. Table 3 interprets the respective signs and relative values of the intra-bloc (RTA2) and extra-bloc (RTAexp and RTAimp) coefficients. Again note that the definitions of the terms import trade diversion and export trade diversion ${ }^{7}$, refer to the definitions in Johnson (1962, p.53) and Endoh (1999), respectively. These definitions differ from the welfare-effect definitions given by Viner (1950, p.43). Thus, it is not possible to conclude that the economic welfare of RTA members has increased based on the fact that estimates from the gravity model indicate that the RTA has led to

\footnotetext{
${ }^{6}$ This procedure was necessary because the number of members in some RTAs was not constant over the sample period, since some countries acceded at a later stage.

${ }^{7}$ Endoh (1999) stated that this term had been introduced for the first time in his paper.
} 
an increase in trade among its members.

Table 3. Trade Creation, Trade Diversion, and Typology of Blocs

\begin{tabular}{|c|c|c|c|c|c|}
\hline \multicolumn{3}{|c|}{ Expected Sign } & \multirow{2}{*}{ Differences in Absolute Size } & \multirow{2}{*}{$\begin{array}{c}\text { Typology of Trade } \\
\text { Creation and Diversion }\end{array}$} & \multirow{2}{*}{$\begin{array}{l}\text { Building (B) vs. Stumbling (S) } \\
\text { Blocs }\end{array}$} \\
\hline$R T A 2$ & RTAexp & RTAimp & & & \\
\hline+ & + & + & & ITC, XTC and MTC & B \\
\hline+ & + & - & RTA2 $>\mid$ RTAimp $\mid$ & ITC, XTC, MTD & $\mathrm{B}$ if RTAexp $>\mid$ RTAimp $\mid$ \\
\hline+ & + & - & RTA2 $<\mid$ RTAimp $\mid$ & XTC, MTD & $\mathrm{B}$ if RTAexp $<\mid$ RTAimp $\mid$ \\
\hline+ & - & + & $R T A 2>|R T A \exp |$ & ITC, XTD, MTC & $\mathrm{B}$ if $\mid$ RTAexp $\mid<$ RTAimp \\
\hline+ & - & + & $R T A 2<|R T A \exp |$ & XTD, MTC & $\mathrm{B}$ if $\mid$ RTAexp $\mid>$ RTAimp \\
\hline+ & - & - & RTA2 $>\mid$ RTAexp + RTAimp $\mid$ & ITC, XTD, MTD & S \\
\hline+ & - & - & RTA2 $<\mid$ RTAexp + RTAimp $\mid$ & XTD and/or MTD & S \\
\hline
\end{tabular}

(Source) Trotignon (2010), Table 4, p.242

Next we provide a survey of the recent literature that is comparable with our research (Table 4). With regard to estimated intra-bloc trade creation, export trade creation/diversion, and import trade creation/diversion, the empirical literature has not reached any consensus. For instance, the ASEAN trade bloc has been found to generate both intra-trade creation (Endoh, 2000; Carrère, 2004; Elliott and lkemoto, 2004) and intra-trade diversion (Soloaga and Winters, 2001; Tumbarello, 2007). 
Table 4. Recent Literature using three Regional Dummy Variables

\begin{tabular}{|c|c|c|c|}
\hline Study & $\begin{array}{l}\text { Empirical } \\
\text { Approach }\end{array}$ & $\begin{array}{c}\text { Period and } \\
\# \text { of countries }\end{array}$ & RTAs and Results \\
\hline Endoh (1999) & OLS & $1960 \sim 1994$ & $\begin{array}{ll}\text { CMEA: } & \text { RTA2 }=(+), \text { RTAexp }=(-), \text { RTAimp }=(-) \\
\text { EEC: } & \text { RTA2 }=(+), \text { RTAexp }=(+), \text { RTAimp }=(+) \\
\text { LAFTA: } & \text { RTA2 }=(-), \text { RTAexp }=(-), \text { RTAimp }=(-)\end{array}$ \\
\hline Endoh (2000) & OLS & 1995 & $\begin{array}{ll}\text { ASEAN: } & \text { RTA } 2=(+), \text { RTAexp }=(+), \text { RTAimp }=(+) \\
\text { APEC } & \\
\text { EAEC } & \text { RTA } 2=(+), \text { RTAexp }=(+), \text { RTAimp }=(+)\end{array}$ \\
\hline $\begin{array}{l}\text { Soloaga and } \\
\text { Winters (2001) }\end{array}$ & Tobit & $\begin{array}{l}1980 \sim 1996 / \\
58 \text { countries }\end{array}$ & $\begin{array}{ll}\text { ANDEAN: } & \text { RTA2 }=(+), \text { RTAexp }=(-), \text { RTAimp }=(-) \\
\text { ASEAN: } & \text { RTA2 }=(-), \text { RTAexp }=(+), \text { RTAimp }=(+) \\
\text { CACM: } & \text { RTA2 }=(+), \text { RTAexp }=(-), \text { RTAimp }=(-) \\
\text { EU: } & \text { RTA2 }=(-), \text { RTAexp }=(+), \text { RTAimp }=(+) \\
\text { EFTA: } & \text { RTA2 }=(n), \text { RTAexp }=(+), \text { RTAimp }=(+) \\
\text { GULFCOOP: } & \text { RTA2 }=(+), \text { RTAexp }=(-), \text { RTAimp }=(\mathrm{n}) \\
\text { LAIA: } & \text { RTA2 }=(+), \text { RTAexp }=(-), \text { RTAimp }=(-) \\
\text { MERCOSUR: } & \text { RTA2 }=(+), \text { RTAexp }=(n), \text { RTAimp }=(-) \\
\text { NAFTA }: & \text { RTA2 }=(n), \text { RTAexp }=(n), \text { RTAimp }=(+)\end{array}$ \\
\hline Carrere (2004) & $\begin{array}{l}\text { Hausman- } \\
\text { Taylor }\end{array}$ & 1962 1996 & $\begin{array}{ll}\text { ANDEAN: } & \text { RTA } 2=(+), \text { RTAexp }=(-), \text { RTAimp }=(-) \\
\text { MERCOSUR: } & \text { RTA2 }=(+), \text { RTAexp }=(+), \text { RTAimp }=(-) \\
\text { ASEAN: } & \text { RTA2 }=(+), \text { RTAexp }=(+), \text { RTAimp }=(+) \\
\text { CEMAC: } & \text { RTA } 2=(+), \text { RTAexp }=(-), \text { RTAimp }=(-) \\
\text { UEMOA: } & \text { RTA2 }=(+), \text { RTAexp }=(-), \text { RTAimp }=(-) \\
\text { ECOWAS: } & \text { RTA }=(+), \text { RTAexp }=(-), \text { RTAimp }=(+) \\
\text { SADC: } & \text { RTA }=(+), \text { RTAexp }=(+), \text { RTAimp }=(-) \\
\text { COMESA: } & \text { RTA2 }=(n), \text { RTAexp }=(-), \text { RTAimp }=(n)\end{array}$ \\
\hline $\begin{array}{l}\text { Croce, Juan-Ramon } \\
\text { and Zhu (2004) }\end{array}$ & Nonlinear & $\begin{array}{l}1978 \sim 2001 / \\
64 \text { countries }\end{array}$ &  \\
\hline $\begin{array}{l}\text { Elliott and lkemoto } \\
\text { (2004) }\end{array}$ & & 1982 1999 & $\begin{array}{ll}\text { ASEAN } & \text { RTA2 }=(+), \text { RTAexp }=(+), \text { RTAimp }=(+) \\
\text { EU: } & \text { RTA2 }=(+), \text { RTAexp }=(+), \text { RTAimp }=(+) \\
\text { NAFTA: } & \text { RTA2 }=(+), \text { RTAexp }=(-), \text { RTAimp }=(-)\end{array}$ \\
\hline $\begin{array}{l}\text { Kien and } \\
\text { Hashimoto (2005) }\end{array}$ & $\begin{array}{l}\text { Hausman- } \\
\text { Taylor }\end{array}$ & $\begin{array}{l}1988 \sim 2002 / \\
39 \text { countries }\end{array}$ & 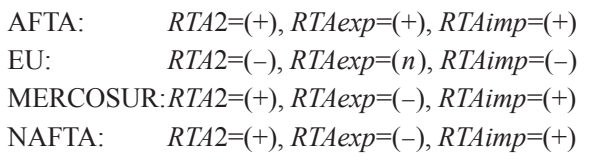 \\
\hline Tumbarello (2007) & $\begin{array}{l}\text { Log linear } \\
\text { OLS }\end{array}$ & $\begin{array}{l}1984 \sim 2005 / \\
182 \text { countries }\end{array}$ & $\begin{array}{ll}\text { ASEAN: } & \text { RTA2 }=(-), \text { RTAexp }=(+), \text { RTAimp }=(+) \\
\text { APEC: } & \text { RTA2 }=(+), \text { RTAexp }=(+), \text { RTAimp }=(+) \\
\text { CER: } & \text { RTA2 }=(+), \text { RTAexp }=(+), \text { RTAimp }=(-) \\
\text { EU-15: } & \text { RTA2 }=(-), \text { RTAexp }=(+), \text { RTAimp }=(+) \\
\text { EAEC: } & \text { RTA } 2=(n), \text { RTAexp }=(+), \text { RTAimp }=(-) \\
\text { MERCOSUR: } & \text { RTA2 }=(+), \text { RTAexp }=(+), \text { RTAimp }=(-) \\
\text { NAFTA: } & \text { RTA2 }=(n), \text { RTAexp }=(-), \text { RTAimp }=(n) \\
\text { SAPTA: } & \text { RTA2 }=(n), \text { RTAexp }=(+), \text { RTAim }=(+)\end{array}$ \\
\hline
\end{tabular}


(Note) 1. (+) : positive and statistically significant, $(-)$ : negative and statistically significant, and (n) : not significant.

2. Definitions of Abbreviations in Table 4:

AFTA : ASEAN Free Trade Area, ANDEAN : ANDEAN Pact, ASEAN : the Association of Southeast Asian Nation, APEC : the Asia-Pacific Economic Cooperation, CACM : the Central American Common Market, CEMAC : the Economic and Monetary Community of Central Africa, CER : the Australia-New Zealand Closer Economic Relations, CMEA : the Council of Mutual Economic Assistance, COMESA : the Common Market for Eastern and Southern Africa, EAEC : East Asia Economic Caucus, EEC : the European Economic Community, ECOWAS : the Economic Community of West African States, EFTA : the European Free Trade Association, EU-15 : the European Union-comprising 15 members, GULFCOOP : Gulf Cooperation Council, LAIA : the Latin American Integration Association, LAFTA : the Latin American Free Trade Association, MERCOSUR : the Southern Common Market, NAFTA : the North American Free Trade Agreement, SADC : the Southern African Development Community, SAPTA : the Agreement on South Asian Association for Regional Cooperation Preferential Trading Arrangement, and UEMOA : the Economic and Monetary Union of West Africa.

The three RTA variables in Equation (1) allow us to give an overall evaluation of regional integration vis-à-vis multilateral trade. We estimate two types of specifications of Equation (1). The first estimation includes three RTA dummy variables for 12 RTAs in a single regression in order to examine the overall effects of trade creation and trade diversion. The second one estimates each RTA alone in 12 separate regressions.

\section{Data}

Trade Data: World Integrated Trade Solution (WITS) - the World Bank.

Data on Regional Integration: The Regional Trade Agreements Information System (RTA-IS) - the World Trade Organization (WTO).

Data on other Control Variables: The data on GDP, GDP per capita, and population size are from the World Economic Outlook Database, IMF. Language data are from the Wikipedia website at http://en .wikipedia.org/wiki. Data for tariffs is from the United Nations TRANIS data, World Integrated Trade Solution (WITS) Database. Exchange rates are obtained from the IFS-IMF. Note that ER is the exchange rate of the importer countries' currency measured by foreign currency per unit of domestic currency. Hence, an increase (decrease) in ER indicates appreciation (depreciation) of the domestic currency. We report summary statistics for all variables in Table 5. 
Table 5. Summary Statistics

\begin{tabular}{|c|c|c|c|c|}
\hline Definition & Mean & Std. Dev. & Min & Max \\
\hline Exports in millions of \$US. & 201.7043 & $3,220.013$ & 0 & 354,687 \\
\hline Importer Population (millions) & 46.16 .341 & 156.8944 & 0.041 & $1,328.02$ \\
\hline Importer GDP of \$US (billions) & 207.8676 & $1,037.469$ & 0.072 & 14,441 \\
\hline Exporter Population (millions) & 36.35258 & 130.7271 & 0.04 & $1,328.02$ \\
\hline Exporter GDP of \$US (billions) & 210.0203 & 909.7945 & 0.03 & 14,441 \\
\hline Importer's Tariff & 14.5904 & 11.35392 & 0 & 106.5 \\
\hline Importer's Exchange Rate (Nati. per \$US) & 0.46887 & 1.601 & 0 & 30.694 \\
\hline Distance & $8,084.103$ & $4,469.764$ & 10.478 & $19,904.45$ \\
\hline Contiguity & 0.0184 & 0.1344 & 0 & 1 \\
\hline Language & 0.1608 & 0.3673 & 0 & 1 \\
\hline AFTA2 & 0.0029 & 0.0542 & 0 & 1 \\
\hline AFTA_imp & 0.0547 & 0.2274 & 0 & 1 \\
\hline AFTA_exp & 0.0457 & 0.2090 & 0 & 1 \\
\hline ADEAN2 & 0.0009 & 0.0308 & 0 & 1 \\
\hline ADEAN_imp & 0.0370 & 0.1888 & 0 & 1 \\
\hline ADEAN_exp & 0.0271 & 0.1624 & 0 & 1 \\
\hline CEMAC2 & 0.0004 & 0.0198 & 0 & 1 \\
\hline CEMAC_imp & 0.0150 & 0.1216 & 0 & 1 \\
\hline CEMAC_exp & 0.0176 & 0.1317 & 0 & 1 \\
\hline CIS2 & 0.0024 & 0.0486 & 0 & 1 \\
\hline CIS_imp & 0.0359 & 0.1859 & 0 & 1 \\
\hline CIS_exp & 0.0510 & 0.2200 & 0 & 1 \\
\hline EAC2 & 0.0005 & 0.0225 & 0 & 1 \\
\hline EAC_imp & 0.0202 & 0.1406 & 0 & 1 \\
\hline EAC_exp & 0.0155 & 0.1236 & 0 & 1 \\
\hline ECOWAS2 & 0.0068 & 0.0824 & 0 & 1 \\
\hline ECOWAS_imp & 0.0799 & 0.2712 & 0 & 1 \\
\hline ECOWAS_exp & 0.0621 & 0.2413 & 0 & 1 \\
\hline GCC2 & 0.0004 & 0.0211 & 0 & 1 \\
\hline GCC_imp & 0.0141 & 0.1177 & 0 & 1 \\
\hline GCC_exp & 0.0114 & 0.1059 & 0 & 1 \\
\hline MERCOSUR2 & 0.0005 & 0.0233 & 0 & 1 \\
\hline MERCOSUR_imp & 0.0285 & 0.1664 & 0 & 1 \\
\hline MERCOSUR_exp & 0.0205 & 0.1419 & 0 & 1 \\
\hline PAFTA2 & 0.00566 & 0.0750 & 0 & 1 \\
\hline PAFTA_imp & 0.05813 & 0.2339 & 0 & 1 \\
\hline PAFTA_exp & 0.05406 & 0.2261 & 0 & 1 \\
\hline
\end{tabular}




\begin{tabular}{|l|c|c|c|c|}
\hline \multicolumn{1}{|c|}{ Definition } & Mean & Std. Dev. & Min & Max \\
\hline SADC2 & 0.00212 & 0.0460 & 0 & 1 \\
SADC_imp & 0.03600 & 0.1863 & 0 & 1 \\
SADC_exp & 0.02507 & 0.1563 & 0 & 1 \\
\hline SAPTA2 & 0.00125 & 0.0353 & 0 & 1 \\
SAPTA_imp & 0.03800 & 0.1912 & 0 & 1 \\
SAPTA_exp & 0.02647 & 0.1605 & 0 & 1 \\
\hline WAEMU2 & 0.00128 & 0.0358 & 0 & 1 \\
WAEMU_imp & 0.03289 & 0.1783 & 0 & 1 \\
WAEMU_exp & 0.02115 & 0.1439 & 0 & 1 \\
\hline Number of observations & 315,742 & & & \\
\hline
\end{tabular}

\section{Econometric Issues}

Recently Anderson and van Wincoop (2003) and Feenstra (2004) showed that the traditional specification of the gravity model suffers from omitted variable bias, as it does not take into account the effect of relative prices on trade patterns. They note that bilateral trade intensity not only depends on bilateral trade costs (affected by spatial distance, language differences, trade restrictions, and so on), but also on weighted multilateral trade cost indices reflecting the prices of import-competing goods in the importing country and export opportunities in the exporting country.

As shown by Anderson and van Wincoop (2003) and Feenstra (2004), a countryspecific fixed-effects specification of the gravity model is in line with the theoretical concerns regarding the correct specifications of the model and yields consistent parameter estimates for the variables of interest. These country-specific-fixedeffects absorb all other time-invariant factors that affect international trade volumes. In particular, when bilateral exports grow faster than GDP, the extent to which total exports grow faster than GDP is an individual country fixed effect, not a country-pair fixed effect. This suggestion is consistent with Matyas (1997) who noted that the correct econometric representation of the gravity model is in the form of a triple-index model: time fixed effect, importer fixed effect, and exporter fixed effect. The time fixed effect makes it possible to monitor common business cycles or globalization trends over the whole sample. This study will follow Matyas (1997) and Anderson and van Wincoop (2003), using the form of a triple-index model. 
In an influential paper on the gravity model, Silva and Tenreyro (2006) focused on the traditional econometric approach to its estimation, raising serious concerns about bias and showing that this bias could be large. They have shown that the log-normal gravity equation suffers from three problems: the bias created by the logarithmic transformation, the failure of the homoskedasticity assumption, and the way zero values are treated. These problems normally result in biased and inefficient estimates.

In order to address these problems, Silva and Tenreyro (2006) propose the Poisson Pseudo-Maximum-Likelihood (PPML) estimation technique and assess its performance using Monte Carlo simulations of aggregated trade flows collected for 136 countries comparing OLS on $\ln \left(T_{i j}\right)$, OLS on $\ln \left(T_{i j}+1\right)$, ET-Tobit ${ }^{8}$ on $\ln \left(T_{i j}+a\right)$, and $\mathrm{NLS}^{9}$. Siliverstovs and Schumacher (2009) confirm the performance of the PPML in comparison to the traditional estimation method using both aggregated trade flows and trade flows broken down by 25 three-digit ISIC Rev.2 industries as well as for manufacturing as a whole.

We adopt the following Silva and Tenreyro (2006, p.47) specification that appears in equation (14) of their paper.

$$
\begin{aligned}
\mathrm{E}\left[T_{i j} \mid x_{i j}\right]= & \mu\left(x_{i j} \beta\right)=\exp \left(x_{i j} \beta\right)=\exp \left[\ln \left(\alpha_{0}\right)+\alpha_{1} \ln \left(Y_{i}\right)+\right. \\
& \left.\alpha_{2} \ln \left(Y_{j}\right)+\alpha_{3} \ln \left(N_{i}\right)+\alpha_{4} \ln \left(N_{j}\right)+\alpha_{5} \ln \left(D_{i j}\right)+\gamma_{i}+\rho_{j}+t\right]
\end{aligned}
$$

Applying the Poisson specification to the fixed effects specification of the gravity model of trade (see Woodridge, 2002, section 19.2) one obtains:

$$
\operatorname{Pr}\left[T_{i j}=T \mid x_{i j}\right]=\frac{\exp \left[-\mu\left(x_{i j} \beta\right)\right]\left[\mu\left(x_{i} \beta\right)\right]^{T_{i j}}}{T_{i j} !},=0,1, \ldots \text { where } T_{i j} ! \text { is } T \text { factorial. }
$$

Note that the Poisson model assumes equi-dispersion, that the conditional variance of $T_{i j}$ is equal to $\mu\left(x_{i j} \beta\right)$.

$$
\operatorname{Var}\left(T_{i j} \mid x_{i j}\right)=\mathrm{E}\left[T_{i j} \mid x_{i j}\right]=\mu\left(x_{i j} \beta\right)
$$

Then $\beta$ can be estimated by means of maximum likelihood. The log-likelihood function is the sum of the appropriate $\log$ probabilities, interpreted as a function of $\beta$.

\footnotetext{
${ }^{8}$ Tobit of Eaton and Tamura (1994).

${ }^{9}$ Non-linear least square.
} 
$\log \mathrm{L}(\beta)=\sum_{i=1}^{N} \sum_{j=1}^{N}\left[-\exp \left(x_{i j} \beta\right)+T_{i j}\left(x_{i j} \beta\right)-\log T_{i j} !\right]$

The first order conditions of maximizing $\log \mathrm{L}(\beta)$ with respect to $\beta$ are given by

$$
\sum_{i=1}^{N} \sum_{j=1}^{N}\left[T_{i j}-\exp \left(x_{i j} \beta\right)\right] x_{i j}=\sum_{i=1}^{N} \sum_{j=1}^{N} \varepsilon_{i j} x_{i j}=0
$$

where $\varepsilon_{i j}=T_{i j}-\exp \left(x_{i j} \beta\right)$.

Since (4) implies that $E\left(\varepsilon_{i j} \mid x_{i j}\right)=0$, we can interpret (8) as the sample moment conditions corresponding to the set of orthogonality conditions $E\left(\varepsilon_{i j} \mid x_{i j}\right)=0$. As a result, the estimator that maximizes (7) is generally consistent under condition (4), even if $T_{i j}$ given $x_{i j}$ does not have a Poisson distribution.

A Pseudo-Maximum-Likelihood (PML) estimator based on equation (8) gives the same weight to all observations. Silva and Tenreyro (2006) suggest that this is because all observations have the same information on the parameters of interest. Assuming that equation (6) holds, the additional information on the curvature of the conditional mean coming from observations with large $x_{i j} \beta$ is offset by their greater variance.

The estimator defined by equation (8) is numerically equal to the Poisson PseudoMaximum-Likelihood (PPML) estimator. All that is needed for this estimator to be consistent is the correct specification of the conditional mean, that is, $\mathrm{E}\left[T_{i j} \mid x_{i j}\right]=\exp \left(x_{i j} \beta\right)$. Therefore, the data do not have to be Poisson at all and the dependent variable can be zero.

In sum, the PPML version of the gravity model does not face the problems outlined in the above section. First, the linking function is log-linear $\left(T_{i j}\right)$ instead of $\log -\log$ $\left(\ln T_{i j}\right)$. Second, in the presence of heteroskedasticity, Poisson regression estimates are consistent and more efficient than the traditional gravity estimations. Third, because of its multiplicative form, the Poisson estimation provides a natural way to deal with zero-valued trade flows. Kepaptsoglou, Karlaftis, and Tsamboulas (2010) reviewed the empirical literature on gravity models analyzing the effects of FTAs on trade undertaken in the last decade (1999 2009). They find that there were only two papers that used the PPML technique among over 55 papers published within the last decade. 


\section{Regression Results}

The estimated coefficients for thirteen regressions are presented in Table 6. The first regression includes all 12 RTAs in a single pooled regression. The rest of the regressions cover each RTA separately. Because of missing observations for many control variables, our panel is unbalanced. In the pooled regression there are 315,742 observations containing 165 exporters and 158 importers over the period of 1981 2008.

The model explains a high proportion - 94 percent - of the total variation of world exports in the single pooled regression and between 79 to 96 percent in the separate RTA regressions. Most of the basic variables of the gravity model - the level of GDP of exporter and importer, importer's tariff, importer's exchange rate, distance, contiguity, and language - have the expected sign and are statistically significant. The coefficients of population for exporter and importer are mixed. The coefficient of exporter GDP and importer GDP is generally between 0.4 and 0.7 , suggesting that trade increases less than proportionately as economic size grows. Distance and common border variables always show the traditional negative sign and positive sign, respectively.

The PPML regressions suggest that during 1981-2008, the various RTA regimes had different impacts on international trade. Outcomes for the pooled regression and individual regressions also differed. This study focuses on the results from the pooled regression because it accounts for the interrelationships among RTAs. Also, we describe the trade creation and diversion effects of each RTA, relate them to stylized facts about policies involved in each RTA, and compare our results with previous studies. Our results are summarized in Table 7 .

Table 6. Intra and Extra-bloc Effects of Trade Agreements

\begin{tabular}{|l|c|c|c|c|c|c|}
\hline & All & AFTA & CAN & CEMAC & CIS & EAC \\
\hline Exporter GDP & $\begin{array}{c}0.782 * * * \\
(0.0506)\end{array}$ & $\begin{array}{c}0.585 * * * \\
(0.0577)\end{array}$ & $\begin{array}{c}0.657 * * * \\
(0.0850)\end{array}$ & $\begin{array}{c}0.854 * * * \\
(0.100)\end{array}$ & $\begin{array}{c}0.076 \\
(0.0732)\end{array}$ & $\begin{array}{c}0.460^{* * *} \\
(0.0126)\end{array}$ \\
\hline Importer GDP & $\begin{array}{c}0.796^{* *} \\
(0.00967)\end{array}$ & $\begin{array}{c}0.798^{* * *} \\
(0.0715)\end{array}$ & $\begin{array}{c}0.971 * * * \\
(0.0822)\end{array}$ & $\begin{array}{c}0.938^{* * *} \\
(0.101)\end{array}$ & $\begin{array}{c}0.337 * * * \\
(0.0758)\end{array}$ & $\begin{array}{c}0.449 * * * \\
(0.0201)\end{array}$ \\
\hline Exporter Pop. & $\begin{array}{c}-0.0118^{* * *} \\
(0.0437)\end{array}$ & $\begin{array}{c}-0.147 \\
(0.0854)\end{array}$ & $\begin{array}{c}2.330^{* * *} \\
(0.3331)\end{array}$ & $\begin{array}{c}3.123 * * * \\
(0.780)\end{array}$ & $\begin{array}{c}0.781 \\
(0.442)\end{array}$ & $\begin{array}{c}1.133 * * * \\
(0.0276)\end{array}$ \\
\hline Importer Pop. & $\begin{array}{c}0.0376^{* *} \\
(0.0116)\end{array}$ & $\begin{array}{c}-0.230^{* * *} \\
(0.0516)\end{array}$ & $\begin{array}{c}-0.0689 \\
(0.1043)\end{array}$ & $\begin{array}{c}0.327 \\
(0.266)\end{array}$ & $\begin{array}{c}0.219 * * \\
(0.0736)\end{array}$ & $\begin{array}{c}0.276 \\
(0.0697)\end{array}$ \\
\hline
\end{tabular}




\begin{tabular}{|c|c|c|c|c|c|c|}
\hline & All & AFTA & CAN & CEMAC & CIS & EAC \\
\hline Importer Tariff & $\begin{array}{c}-0.0847 * * * \\
(0.0177)\end{array}$ & $\begin{array}{c}-0.235^{* * *} \\
(0.0455)\end{array}$ & $\begin{array}{c}-0.180 * * \\
(0.0684)\end{array}$ & $\begin{array}{l}-0.0245 \\
(0.147)\end{array}$ & $\begin{array}{c}-0.141 * * \\
(0.0476)\end{array}$ & $\begin{array}{c}0.0407 \\
(0.0151)\end{array}$ \\
\hline Exchange Rate & $\begin{array}{c}0.00929 \\
(0.00490)\end{array}$ & $\begin{array}{c}-0.0895^{*} \\
(0.0379)\end{array}$ & $\begin{array}{r}-0.00431 \\
(0.0091)\end{array}$ & $\begin{array}{l}-0.0464 \\
(0.0248)\end{array}$ & $\begin{array}{c}0.0314 \\
(0.0333)\end{array}$ & $\begin{array}{c}-0.0611 * * * \\
(0.00361)\end{array}$ \\
\hline Distance & $\begin{array}{c}-0.644 * * * \\
(0.0115)\end{array}$ & $\begin{array}{c}-0.711^{* * * *} \\
(0.0292)\end{array}$ & $\begin{array}{c}-1.717 * * * \\
(0.0910)\end{array}$ & $\begin{array}{c}0.257 \\
(0.202)\end{array}$ & $\begin{array}{c}-0.791 * * * \\
(0.0559)\end{array}$ & $\begin{array}{c}-2.883 * * * \\
(0.0352)\end{array}$ \\
\hline Contiguity & $\begin{array}{c}0.855 * * * \\
(0.0318) \\
\end{array}$ & $\begin{array}{l}-0.0159 \\
(0.0512) \\
\end{array}$ & $\begin{array}{c}0.120 \\
(0.1195) \\
\end{array}$ & $\begin{array}{c}4.213 * * * \\
(0.330)\end{array}$ & $\begin{array}{c}0.255^{* * *} \\
(0.0670)\end{array}$ & $\begin{array}{c}-0.196 \\
(0.0267) \\
\end{array}$ \\
\hline Language & $\begin{array}{c}0.561 * * * \\
(0.0220)\end{array}$ & $\begin{array}{c}0.133 * * * \\
(0.0358)\end{array}$ & $\begin{array}{c}0.542 * \\
(0.2734)\end{array}$ & $\begin{array}{c}-0.280^{* *} \\
(0.108)\end{array}$ & $\begin{array}{c}0.819^{* * *} \\
(0.0979)\end{array}$ & $\begin{array}{c}0.0269 \\
(0.0106)\end{array}$ \\
\hline AFTA2 & $\begin{array}{c}0.529 * * * \\
(0.0793)\end{array}$ & $\begin{array}{c}0.733 * * * \\
(0.166)\end{array}$ & & & & \\
\hline AFTA_exp & $\begin{array}{c}0.0214 \\
(0.0647)\end{array}$ & $\begin{array}{c}0.591 * * * \\
(0.153)\end{array}$ & & & & \\
\hline AFTA_imp & $\begin{array}{c}0.758 * * * \\
(0.0352)\end{array}$ & $\begin{array}{l}0.389^{*} \\
(0.157)\end{array}$ & & & & \\
\hline ADEAN2 & $\begin{array}{c}0.363 \\
(0.209)\end{array}$ & & $\begin{array}{c}0.567^{*} \\
(0.2679)\end{array}$ & & & \\
\hline ADEAN_exp & $\begin{array}{l}0.0211 \\
(0.204) \\
\end{array}$ & & $\begin{array}{c}0.295^{*} \\
(0.2679) \\
\end{array}$ & & & \\
\hline ADEAN_imp & $\begin{array}{c}-0.497 * * * \\
(0.0271)\end{array}$ & & $\begin{array}{c}0.264 \\
(0.1357)\end{array}$ & & & \\
\hline CEMAC2 & $\begin{array}{l}-0.608 \\
(0.355)\end{array}$ & & & $\begin{array}{c}-2.116^{* * *} \\
(0.382)\end{array}$ & & \\
\hline CEMAC_exp & $\begin{array}{c}0.279 \\
(0.174)\end{array}$ & & & $\begin{array}{c}-1.245^{* * *} \\
(0.248)\end{array}$ & & \\
\hline CEMAC_imp & $\begin{array}{c}-0.533 * * * \\
(0.0811)\end{array}$ & & & $\begin{array}{c}-0.885^{* * *} \\
(0.183)\end{array}$ & & \\
\hline CIS2 & $\begin{array}{c}1.008 * * * \\
(0.172)\end{array}$ & & & & $\begin{array}{c}2.258^{* * *} \\
(0.438)\end{array}$ & \\
\hline CIS_exp & $\begin{array}{c}-0.454^{* *} \\
(0.158) \\
\end{array}$ & & & & $\begin{array}{c}1.219^{* * *} \\
(0.224)\end{array}$ & \\
\hline CIS_imp & $\begin{array}{c}-0.416^{* * *} \\
(0.0546)\end{array}$ & & & & $\begin{array}{c}1.288^{* * *} \\
(0.227)\end{array}$ & \\
\hline EAC2 & $\begin{array}{c}2.267 * * * \\
(0.154)\end{array}$ & & & & & $\begin{array}{c}0.508^{*} \\
(0.0331)\end{array}$ \\
\hline EAC_exp & $\begin{array}{c}-0.421^{* *} \\
(0.135)\end{array}$ & & & & & $\begin{array}{c}0.361^{*} \\
(0.0307) \\
\end{array}$ \\
\hline EAC_imp & $\begin{array}{c}-0.445 * * * \\
(0.0560)\end{array}$ & & & & & $\begin{array}{l}0.420 * * \\
(0.0280)\end{array}$ \\
\hline
\end{tabular}

(Note) Standard errors in parentheses $* p<0.05 * * p<0.01 * * * p<0.001$ 
Table 6. Intra and Extra-bloc Effects of Trade Agreements

(Continued 2/3)

\begin{tabular}{|c|c|c|c|c|c|c|}
\hline & All & ECOWAS & GCC & MERCOSUR & PAFTA & SADC \\
\hline Exporter GDP & & $\begin{array}{c}0.632 * * * \\
(0.0754)\end{array}$ & $\begin{array}{c}0.599 * * * \\
(0.898)\end{array}$ & $\begin{array}{c}0.456 * * * \\
(0.0545)\end{array}$ & $\begin{array}{c}0.568 * * * \\
(0.0692)\end{array}$ & $\begin{array}{c}0.537 * * * \\
(0.122)\end{array}$ \\
\hline Importer GDP & & $\begin{array}{c}0.608 * * * \\
(0.0417)\end{array}$ & $\begin{array}{c}1.163^{* * *} \\
(0.503)\end{array}$ & $\begin{array}{c}0.932 * * * \\
(0.029)\end{array}$ & $\begin{array}{c}1.152 * * * \\
(0.0303)\end{array}$ & $\begin{array}{c}0.711 * * * \\
(0.159)\end{array}$ \\
\hline Exporter Pop. & & $\begin{array}{c}1.273 * * * \\
(0.274)\end{array}$ & $\begin{array}{c}0.302 \\
(0.192)\end{array}$ & $\begin{array}{c}0.631 * * \\
(0.222)\end{array}$ & $\begin{array}{l}0.0718 \\
(0.121)\end{array}$ & $\begin{array}{c}0.653 \\
(0.438)\end{array}$ \\
\hline Importer Pop. & & $\begin{array}{c}0.291 * * * \\
(0.0684)\end{array}$ & $\begin{array}{l}-0.113^{*} \\
(0.057)\end{array}$ & $\begin{array}{c}-0.253 * * * \\
(0.0371)\end{array}$ & $\begin{array}{c}-0.399 * * * \\
(0.0322)\end{array}$ & $\begin{array}{l}-0.728 \\
(0.419)\end{array}$ \\
\hline Importer Tariff & & $\begin{array}{l}0.00987 \\
(0.0860)\end{array}$ & $\begin{array}{c}0.269^{* * *} \\
(0.046)\end{array}$ & $\begin{array}{c}0.163 * * * \\
(0.0438)\end{array}$ & $\begin{array}{c}0.139 * * * \\
(0.0405)\end{array}$ & $\begin{array}{c}0.125 \\
(0.0693)\end{array}$ \\
\hline Exchange Rate & & $\begin{array}{c}-0.0573 * * * \\
(0.0156)\end{array}$ & $\begin{array}{c}-0.297 * * * \\
(0.043)\end{array}$ & $\begin{array}{c}-0.012 \\
(0.0112)\end{array}$ & $\begin{array}{c}-0.178^{* * *} \\
(0.0243)\end{array}$ & $\begin{array}{c}0.0152 \\
(0.0125)\end{array}$ \\
\hline Distance & & $\begin{array}{c}-0.0922 \\
(0.0592)\end{array}$ & $\begin{array}{c}-1.338^{* * *} \\
(0.066)\end{array}$ & $\begin{array}{c}-0.470 * * * \\
(0.0265)\end{array}$ & $\begin{array}{c}-1.096^{* * *} \\
(0.0295)\end{array}$ & $\begin{array}{c}-0.481 * * * \\
(0.122)\end{array}$ \\
\hline Contiguity & & $\begin{array}{c}0.888^{* * * *} \\
(0.117)\end{array}$ & $\begin{array}{c}-0.447 * * * \\
(0.095)\end{array}$ & $\begin{array}{c}0.453 * * * \\
(0.0818)\end{array}$ & $\begin{array}{c}-0.699 * * * \\
(0.0775)\end{array}$ & $\begin{array}{c}1.606^{* * *} \\
(0.176)\end{array}$ \\
\hline Language & & $\begin{array}{l}1.166 * * * \\
(0.0495)\end{array}$ & $\begin{array}{c}0.353 * * * \\
(0.067)\end{array}$ & $\begin{array}{c}0.107 * \\
(0.0518)\end{array}$ & $\begin{array}{c}0.344 * * * \\
(0.0438)\end{array}$ & $\begin{array}{c}0.307 * * \\
(0.114)\end{array}$ \\
\hline ECOWAS2 & $\begin{array}{c}1.284 * * * \\
(0.208)\end{array}$ & $\begin{array}{c}1.713 * * * \\
(0.206)\end{array}$ & & & & \\
\hline ECOWAS_exp & $\begin{array}{l}0.0989 \\
(0.191)\end{array}$ & $\begin{array}{c}0.618 \\
(0.735)\end{array}$ & & & & \\
\hline ECOWAS_imp & $\begin{array}{c}-0.156 * * \\
(0.0535)\end{array}$ & $\begin{array}{c}0.172 \\
(0.105)\end{array}$ & & & & \\
\hline GCC2 & $\begin{array}{c}-1.120^{* * *} \\
(0.132)\end{array}$ & & $\begin{array}{c}-0.823 * * * \\
(0.160)\end{array}$ & & & \\
\hline GCC_exp & $\begin{array}{c}0.0925 \\
(0.0977)\end{array}$ & & $\begin{array}{c}0.203 \\
(0.135)\end{array}$ & & & \\
\hline GCC_imp & $\begin{array}{l}0.165^{* *} \\
(0.0558)\end{array}$ & & $\begin{array}{c}-0.352 * * * \\
(0.101)\end{array}$ & & & \\
\hline MERCOSUR2 & $\begin{array}{r}0.685^{* * *} \\
(0.0962)\end{array}$ & & & $\begin{array}{c}0.961 * * * \\
(0.107)\end{array}$ & & \\
\hline MERCOSUR_exp & $\begin{array}{c}0.0448 \\
(0.0679)\end{array}$ & & & $\begin{array}{l}0.294^{* *} \\
(0.0999)\end{array}$ & & \\
\hline MERCOSUR_imp & $\begin{array}{c}-0.452 * * * \\
(0.0583)\end{array}$ & & & $\begin{array}{c}0.583 * * * \\
(0.0935)\end{array}$ & & \\
\hline
\end{tabular}




\begin{tabular}{|c|c|c|c|c|c|c|}
\hline & All & ECOWAS & GCC & MERCOSUR & PAFTA & SADC \\
\hline PAFTA2 & $\begin{array}{c}-0.421 * * * \\
(0.0937)\end{array}$ & & & & $\begin{array}{l}-0.271 * \\
(0.122)\end{array}$ & \\
\hline PAFTA_exp & $\begin{array}{l}0.258^{* *} \\
(0.0928)\end{array}$ & & & & $\begin{array}{c}0.548^{* * *} \\
(0.108)\end{array}$ & \\
\hline PAFTA_imp & $\begin{array}{c}0.0491 \\
(0.0351)\end{array}$ & & & & $\begin{array}{c}0.0346 \\
(0.0988)\end{array}$ & \\
\hline SADC2 & $\begin{array}{c}2.087 * * * \\
(0.180)\end{array}$ & & & & & $\begin{array}{c}0.413 \\
(0.219)\end{array}$ \\
\hline SADC_exp & $\begin{array}{c}0.717 * * * \\
(0.132)\end{array}$ & & & & & $\begin{array}{c}0.601 * * * \\
(0.172)\end{array}$ \\
\hline SADC_imp & $\begin{array}{c}0.130^{*} \\
(0.0618)\end{array}$ & & & & & $\begin{array}{l}-0.0122 \\
(0.153)\end{array}$ \\
\hline
\end{tabular}

(Note) Standard errors in parentheses $* p<0.05 * * p<0.01 * * * p<0.001$ 


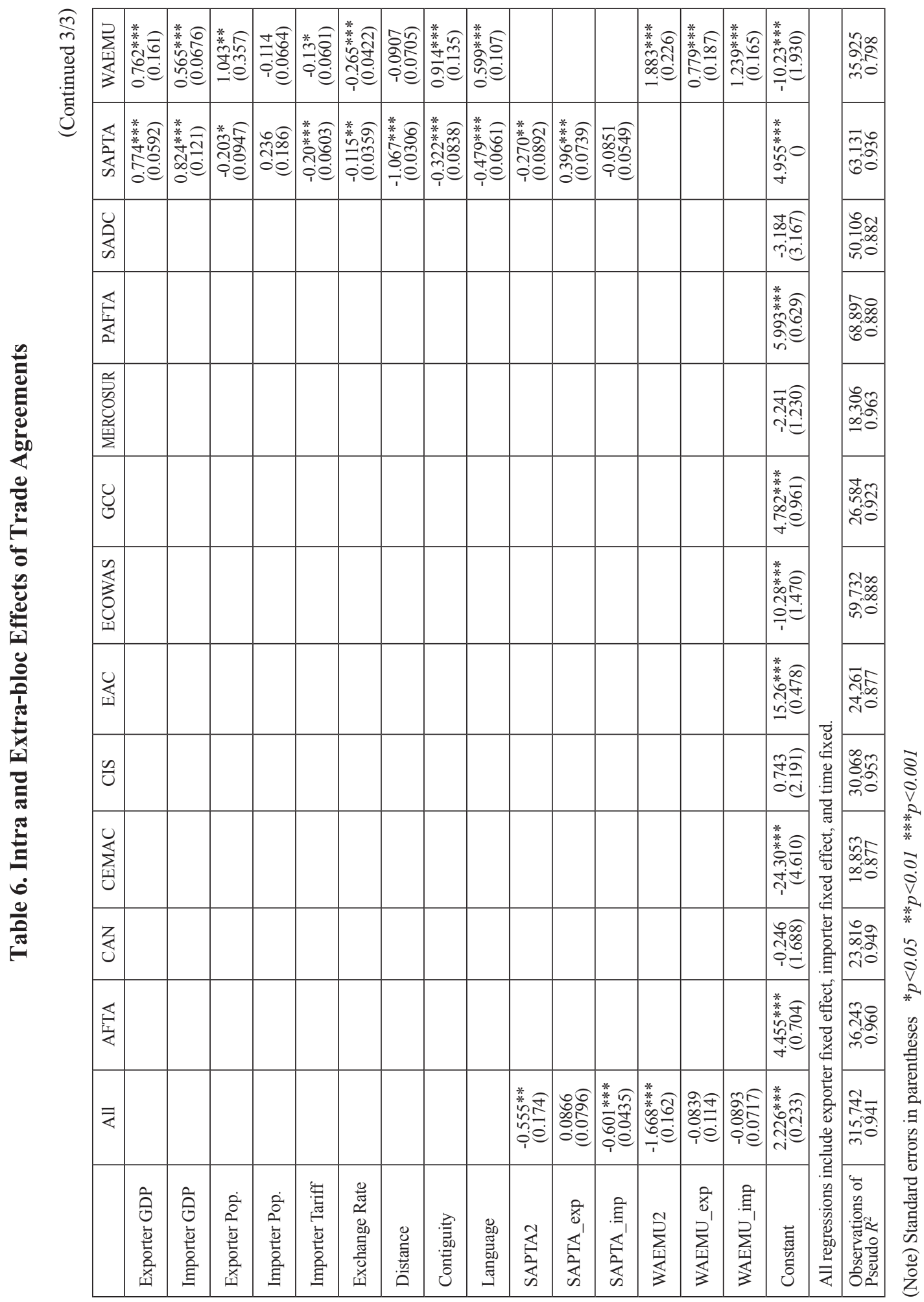




\section{A. AFTA (ASEAN Free Trade Area)}

: Brunei Draussalam, Cambodia, Indonesia, Laos, Malaysia, Myanmar, Philippines, Singapore, Thailand, Vietnam

Both our pooled regression and individual AFTA regressions contain coefficients for AFTA2 and AFTA_imp that are positive and statistically significant. This suggests that countries located within these regions give rise to intra-bloc trade creation and import trade creation. Different findings are found in the previous results in Table 4. Results show that the intra-regional trade for AFTA has increased to a higher level of 0.53. This means that AFTA members trade with each other at a level that is about $69^{10}$ percent higher than without AFTA. This result shows that even though this study includes ASEAN new-comers Cambodia, Lao P.D.R., Myanmar, and Vietnam, AFTA still fostered trade flows among members. These newcomer members still have MFN tariff rates above those of other AFTA members and they have a low trade share in the region.

A positive sign for the $A F T A$ imp variable suggests that AFTA members have not diverted their imports from non-members to members. One plausible explanation for this is the fact that AFTA members were engaged in a long period of multilateral trade liberalization during the 1980s and 1990s. Thus, regional integration efforts proceeded in parallel with multilateral liberalization.

\section{B. ANDEAN (Andean Community)}

: Bolivia, Columbia, Ecuador, Peru, Venezuela

Previous studies also have differed with respect to finding intra-ANDEAN trade creation, although the majority concluded that there was external trade diversion. We estimate that there was import trade diversion because $A N D E A N \_i m p$ is significant and negative in our pooled regression. On the other hand, the RTA among Bolivia, Columbia, Ecuador, Peru, and Venezuela seems to have left the trade pattern of their members unchanged during 1981-2008. This can be seen from the insignificant coefficient of $A N D E A N 2$ and $A N D E A N \_\exp$.

This result may not be surprising in light of the import substitution policies that

\footnotetext{
${ }^{10}\left[\left(e^{0.53}-1\right) * 100 \%\right]$
} 
characterized South America when the first Andean pact was established. This trade bloc has tried to become more outward oriented but it also has been weakened by members that have seceded and re-joined the debt crises of early $1980 \mathrm{~s}$.

\section{CEMAC (Economic and Monetary Community of Central Africa)}

: Cameroon, Central African Republic, Chad, Equatorial Guinea, Gabon, Republic of Congo

A previous study by Carrere (2004) found intra-bloc trade creation, but both our pooled and individual CEMAC regressions suggest that there is trade diversion. The CEMAC_imp dummy is the only significant variable in the pooled regression and it was negative. The lack of significant trade changes in our regressions would seem to be consistent with the disruptions caused by violent conflicts in this region, conflicts that have even forced the relocation of the CEMAC headquarters more than once.

\section{CIS (Commonwealth of Independent States)}

: Armenia, Azerbaijan, Belarus, Georgia, Kazakhstan, Kyrgyz Republic, Moldova, Russia, Tajikistan , Ukraine, Uzbekistan

Our pooled regression results in Table 6 suggest that the CIS is associated with intrabloc trade creation, export trade diversion, and import trade diversion, one of the most extreme cases of a stumbling block to multilateral trade integration. PPML estimates show that intra-regional trade has increased by about 100 percent. On the other hand, the results suggest that CIS members have preferred imports from other members and exports to other members. On balance, the sum of the coefficients of the three dummy variables $(1.008+(-0.454)+(-0.416))$ is equal to 0.138 . This implies that the CIS tends to generate slightly more trade among its members than any non-CIS random country pairs.

The inward orientation of trade in the CIS may reflect the transition of the Soviet Union into newly independent countries facing many impediments to trade with outside of the CIS. New currencies with unstable exchange rates and risky clearing arrangements; poor quality production; delays in accessions to the WTO; the loss of preferential trade with Eastern Europe as the latter became associated with the European Union; the continuation of Russia as the dominant trading partner; the persistence of 
strong intra-bloc trade complementarities left over from the era of central plans. All of these policy-related factors have contributed to the evolution of the CIS as a closed trading bloc.

\section{E. EAC (East African Community)}

: Burundi, Kenya, Rwanda, Tanzania, Uganda

Our pooled regression results in Table 6 show that the EAC experienced intra-bloc trade creation, export trade diversion, and import trade diversion. The EAC agreement seems to have increased trade among its members by around 226 percent. This is shown by the positive and significant coefficient of the EAC2-dummy. However the $E A C_{-}$ import and EAC_export dummies are negative and significant. On balance, the sum of the coefficients of the three dummy variables $(2.267+(-0.421)+(-0.445))$ equal 1.401 . This indicates that the EAC seems to have more intra-trade flows among its members than non-EAC random country pairs.

Our results identify the EAC as favorable to trade regionalization. The three members of the EAC (Kenya, Tanzania, Uganda) have a long history of regional integration and have been one of the more peaceful regions of Africa. They joined the WTO in 1995 but they maintained a relatively high common external tariff on agricultural products. EAC trade may have been affected by high tariffs, warring neighbors, as well as the long-term secular decline in world demand for traditional African products.

\section{F. ECOWAS (Economic Community of West Africa)}

: Benin, Burkina Faso, Cape Verde, Côte d'Ivoire, Gambia, Ghana, Guinea, Guinea-Bissau, Liberia , Mali, Niger, Nigeria, Senegal, Sierra Leone, Togo

The ECOWAS established a FTA in 1996 and a common external tariff in 2000, but a number of nontariff barriers remain and violence has also disrupted trade. Dollar pricing of exports and euro prices for imports may have adversely affected the external trade of the bloc. Our pooled regression results indicate that the ECOWAS displays intra-bloc trade creation and import trade diversion. If two countries are the members of the ECOWAS, trade between them is 128 percent more than without the ECOWAS. 
Also the ECOWAS appears to have 15.6 percent more imports among its members than without the ECOWAS. These results are similar to those of Carrere (2004).

\section{G. GCC (Gulf Cooperation Council)}

: Bahrain, Kuwait, Oman, Qatar, Saudi Arabia, United Arab Emirates

The GCC launched a customs union in 2003 with a relatively low common external tariff. This regional grouping is strongly specialized in exporting a single commodity to the rest of the world and importing goods with virtually no domestically produced substitutes. Our pooled regression shows that the GCC appears to have intra-bloc trade diversion and extra-bloc import trade creation. If two countries are members of the GCC, then trade flows between them average 112 percent less than two similar countries. However, the coefficient of the GCC_imp dummy can be interpreted to mean that the GCC agreement increases imports between its members and the rest of the world by approximately 16.5 percent. Our results are consistent with Al-Atrash and Yousef (2000) who found no trade creation among member countries. On the other hand, we differ from Soloaga and Winters (2001) who found significant trade creation among member countries.

\section{H. MERCOSUR (Southern Common Market)}

: Argentina, Brazil, Paraguay, Uruguay

Despite setbacks to trade following the Asian financial crisis, Brazil's currency devaluation, and the prolonged economic crisis in Argentina, MERCOSUR did make substantial cuts in internal and external tariff rates. Our pooled regression results indicate intra-bloc trade creation and import trade diversion. If two countries are members of MERCOSUR, then trade flows between them average 68 percent higher than two similar countries. On the other hand, the coefficient of the MERCOSUR_imp dummy can be interpreted to mean that the MERCOSUR decreases imports between its members and the rest of the world by about 45 percent. Our result is consistent with Soloaga and Winters (2001) and Croce, Juan-Ramon, and Zhu (2004). They also found that trade integration and trade diversion went hand in hand in MERCOSUR. 


\section{PAFTA (Pan-Arab Free Trade Area)}

: Algeria, Bahrain, Egypt, Iraq, Jordan, Kuwait, Lebanon, Libya, Morocco, Oman, Qatar, Saudi Arabia, Syrian Arab Republic, Tunisia, United Arab Emirates

The PAFTA was initiated in 1981 but did not complete its FTA until 2005. Little is known about the implementation of the FTA but many nontariff barriers remain in force and it is apparently overlapped with the GCC. PAFTA appears to have intra-trade diversion and export trade creation. Our PPML regression indicates that if two countries are members of PAFTA, then trade flows between them are 42 percent lower than two similar countries.

\section{J. SADC (Southern Africa Development Community)}

: Angola, Botswana, Democratic Republic of the Congo, Lesotho, Madagascar, Malawi, Mauritius, Mozambique, Seychelles, South Africa, Swaziland, Tanzania, Zambia, Zimbabwe

The SADC was established in 1992 but only agreed on an FTA in 2004. Its multilateral liberalization was largely associated with the lifting of sanctions on South Africa in the 1990s. The SADC is the only RTA in our pooled regression with three dummies (SADC2,SADC_exp, and $S A D C_{-}$imp) that are positive and statistically significant. This means that countries located within this region give rise to intra-bloc trade creation, import trade creation, and export trade creation. These results show that SADC members have traded with each other about 208 percent more than without the RTA. In sum, our PPML estimates place SADC as a building block, favorable to both regional integration and globalization.

\section{K. SAPTA (South Asian Preferential Trade Agreement)}

: Bangladesh, Bhutan, India, Maldives, Nepal, Pakistan, Sri Lanka

Tumbarello (2007) found import and export trade creation, but our pooled regression indicates intra-bloc trade diversion and import trade diversion. According to our results, SAPTA does not seem to have fostered trade flows among members to any greater extent than trade with non-members. PPML estimates indicate that intra-regional trade 
for SAPTA has decreased to a lower level of 0.55, implying that SAPTA members have traded with each other about 42 percent less than the level predicted in the benchmark context. Also SAPTA membership appears to have been associated with import trade diversion. This can be seen from the negative coefficient of the SAPTA_imp dummy.

Our results are consistent with the World Bank (2004) report on South Asia's trade. It argued that a RTA in South Asia would lead to substantial trade diversion rather than trade creation and considers an RTA in the region as a stumbling block to multilateral trade liberalization. This conclusion was based on the member countries unwillingness to lift tariff and non-tariff barriers on either a preferential or multilateral basis in the early years. In addition, the political problems between India and Pakistan inhibited further trade liberalization and negotiations.

\section{WAEMU (West Africa Economic and Monetary Union)}

: Benin, Burkina Faso, Côte d'Ivoire, Guinea - Bissau, Mali, Niger, Senegal, Togo

All members of the WAEMU belong to the ECOWAS, but they did not perform as well as the ECOWAS. In the case of the WAEMU, our PPML estimates identified only intra-bloc trade diversion as significant. PPML indicates that the intra-regional trade for the WAEMU has decreased to a lower level of 1.67, implying that WAEMU members have traded with each other about 81 percent less than the level predicted in the benchmark context. Our results contrast with those of Carrere (2004) who found positive intra-bloc trade creation.

\section{Conclusion}

Using a modified gravity equation, this study investigates the effects of RTAs on world and regional trade patterns, concentrating on data for 12 developing-country RTAs covering 1981 2008. The effects of RTAs are captured by dummies that reflect intra-bloc trade, import extra-bloc trade, and export extra-bloc trade separately. Our regressions using the PPML technique occasionally give different results than those of previous studies. These trade effects are summarized for each RTA in Table 7.

Our first main finding is that not all of the RTAs succeed in giving rise to intra-bloc 
trade creation. Some RTAs, namely SAPTA, GCC, PAFTA, and WAEMU, are found to have negative intra-bloc effects. For most of these RTAs, this may be largely the result of a failure to eliminate tariffs and non-tariff barriers across the board for imports from member countries.

Our second major result is that seven of the 12 RTAs in the sample generate import trade diversion while most of the export extra-bloc trade dummies are not statistically significant. In many cases, members have not lowered restrictions on imports from non-member states and they have not been able to increase the competitiveness of their exports in world markets. Overall, these results suggest that regional integration is a poor substitute for multilateral trade liberalization.

The third finding of interest is that three of the five African RTAs in the sample have generated intra-bloc trade. They accomplished this despite severe political and economic problems. Only in the case of SADC, a RTA has been able to increase external exports and imports as well. The trade creating RTAs in Africa have been relatively peaceful and they have engaged in multilateral trade liberalization as well.

Our fourth finding is that the results for the pooled regression and the results for individual regressions are different. Simultaneous estimation for all 12 RTAs in a single regression enables us to avoid bias in the results by accounting for interactions among RTAs. 
Table 7. Summary of Regression Results

\begin{tabular}{|c|c|c|c|}
\hline Region & RTA & Type & Regression Results \\
\hline South East Asia & $\begin{array}{l}\text { ASEAN Free Trade } \\
\text { Agreement }\end{array}$ & FTA & $\begin{array}{l}\text { RTA2 }=(+), \text { RTAexp }=(\mathrm{n}), \\
\text { RTAimp }=(+)\end{array}$ \\
\hline South-Asia & $\begin{array}{l}\text { Southern Asian } \\
\text { Preferential Trade } \\
\text { Agreement }\end{array}$ & PTA & $\begin{array}{l}\text { RTA2 }=(-), \text { RTAexp }=(\mathrm{n}), \\
\text { RTAimp }=(-)\end{array}$ \\
\hline Western Hemisphere & Andean Community & $\mathrm{CU}$ & $\begin{array}{l}\text { RTA2 }=(\mathrm{n}), \text { RTAexp }=(\mathrm{n}) \\
\text { RTAimp }=(-)\end{array}$ \\
\hline Western Hemisphere & Southern Common Market & CU \& EIA & $\begin{array}{l}\text { RTA2 }=(+), \text { RTAexp }=(\mathrm{n}) \\
\text { RTAimp }=(-)\end{array}$ \\
\hline Europe and Central Asian & $\begin{array}{l}\text { Commonwealth of } \\
\text { Independent States }\end{array}$ & FTA & $\begin{array}{l}\text { RTA2 }=(+), \text { RTAexp }=(-), \\
\text { RTAimp }=(-)\end{array}$ \\
\hline Middle East & Gulf Cooperation Council & $\mathrm{CU}$ & $\begin{array}{l}\text { RTA2 }=(-), \text { RTAexp }=(\mathrm{n}), \\
\text { RTAimp }=(+)\end{array}$ \\
\hline Middle East \& North Africa & $\begin{array}{l}\text { Pan-Arab Free } \\
\text { Trade Area }\end{array}$ & FTA & $\begin{array}{l}\text { RTA2 }=(-), \text { RTAexp }=(+), \\
\text { RTAimp }=(\mathrm{n})\end{array}$ \\
\hline Sub-Saharan African & $\begin{array}{l}\text { Economic and Monetary } \\
\text { Community of Central } \\
\text { Africa }\end{array}$ & $\mathrm{CU}$ & $\begin{array}{l}\text { RTA2 }=(\mathrm{n}), \operatorname{RTA\operatorname {exp}}=(\mathrm{n}), \\
\text { RTAimp }=(-)\end{array}$ \\
\hline Sub-Saharan African & East African Community & $\mathrm{CU}$ & $\begin{array}{l}\text { RTA2 }=(+), \text { RTAexp }=(-), \\
\text { RTAimp }=(-)\end{array}$ \\
\hline Sub-Saharan African & $\begin{array}{l}\text { Economic Community } \\
\text { of West Africa }\end{array}$ & $\mathrm{CU}$ & $\begin{array}{l}\text { RTA2 }=(+), \text { RTAexp }=(\mathrm{n}) \\
\text { RTAimp }=(-)\end{array}$ \\
\hline Sub-Saharan African & $\begin{array}{l}\text { Southern Africa } \\
\text { Development Community }\end{array}$ & FTA & $\begin{array}{l}\text { RTA2 }=(+), \text { RTAexp }=(+), \\
\text { RTAimp }=(+)\end{array}$ \\
\hline Sub-Saharan African & $\begin{array}{l}\text { West Africa Economic } \\
\text { and Monetary Union }\end{array}$ & $\mathrm{CU}$ & $\begin{array}{l}\text { RTA2 }=(-), \operatorname{RTAexp}=(\mathrm{n}) \\
\text { RTAimp }=(\mathrm{n})\end{array}$ \\
\hline
\end{tabular}

(Source) Authors' results

Received 28 June 2011, Revised 17 May 2013, Accepted 12 September 2013 


\section{References}

Aitken, N. D. (1973). The Effect of the EEC and EFTA on European Trade: a Temporal Cross Section Analysis. American Economic Review, 63, 881-892.

Al-Atrash, H., \& Yousef, T. (2000). Intra-Arab Trade: Is it Too Little. IMF Working Paper (WP/00/10).

Anderson, J. E., \& van Wincoop, E. (2003). Gravity with Gravitas: ASolution to the Border Puzzle. The American Economic Review, 93 (1), 170-192.

Bayoumi, T., \& Eichengreen, B. (1995). Is regionalism simply a diversion? Evidence from the evolution of the EC and EFTA. CEPR Discussion Paper No.1294.

Bhagwati , J., \& Panagariya, A. (1996). The Economics of Preferential Trade Agreement. Washington DC.: AEI Press.

Bhagwati, J., \& Krueger, A. (1995). The Dangerous Drift to Preferntail Trade Agreements. Washington DC.: AEI Press.

Carrère, C. (2004). African Regional Agreements: Impact on Trade with or without Currency Unions. Journal of African Economies, 13 (2), 199-239.

Carrère, C. (2006). Revisiting the Effects of Regional Trade Agreements on Trade Flows with Proper Specification of the Gravity Model. European Economic Review, 50, 223-247.

Cernat, L. (2001). Assessing Regional Trade Arrangements: Are South-South RTAs More Trade Diverting? Global Economy Quarterly, 2, 235-260.

Croce, E., Juan-Ramon, V. H., \& Zhu, F. (2004). Performance of Western Hemisphere Trading Blocs: A CostCorrected Gravity Approach. IMF Working Paper (WP/04/109).

Dee, P., \& Gali, J. (2005). The Trade and Investment Effects of Preferential Trading Arrangements. In T. Ito, \& A. K. Rose, International Trade in East Asia (pp. 133-176). University of Chicago Press.

Deltas, G., Desmet, K., \& Facchini, G. (2006). Hub-and-Spoke Free Trade Areas. CEPR Discussion Paper, No. 5960 .

Elliott, R. J., \& lkemoto, K. (2004). AFTA and the Asian Crisis: Help or Hindrance to ASEAN Intra-Regional Trade? Asian Economic Journal, 18 (1), 1-23.

Endoh, M. (2000). The Transition of Postwar Asia-Pacific Trade Relations. Journal of Asian Economics, 10, 571-587.

Endoh, M. (1999). Trade creation and trade diversion in the EEC, the LAFTA and the CMEA: 1960-1994. Applied Economics, 31, 207-216.

Ethier, W. J. (1998). The new regionalism. The Economic Journal , 108, 1149-1161.

Feenstra, R. C. (2004). Advance International Trade: Theory and Evidence. Princeton, NJ: Princeton University Press.

Foroutan, F., \& Pritchett, L. (1993). Intra-Sub-Saharan African Trade: Is It Too Little? Journal of African Economies, 74-105.

Frankel, J. A. (1997). Regional Trading Blocs in the World Economic System. Washington, DC.: Institute for International Economics. 
Hamilton, C. B., \& Winters, L. A. (1992). Opening up international trade with Eastern Europe. Economic Policy, 14, 77-116.

Johnson, H. G. (1962). Money, Trade and Economic Growth: Survey Lectures in Economic Theory. London: George Allen and Unwin.

Kepaptsoglou, K., Karlaftis, M. G., \& Tsamboulas, D. (2010). The Gravity Model Specification flor Modeling Internaitonal Trade Flows and Free Trade Agreement Effects: A 10-Year Review of Empirical Studies. The Open Economics Journal, 3, 1-13.

Kien, N. T., \& Hashimoto, Y. (2005). Economic Analysis of ASEAN Free Trade Area-By A Country Panel Data. Retrieved December 2010, from http://www2.econ.osaka-u.ac.jp/library/global/dp/0512.pdf

Matyas, L. (1997). Proper econometric specification of the gravity model. The World Economy, 20, 262-302.

Rivera-Batiz, L. A., \& Oliva, M.-A. (2003). International trade: theory, strategies, and evidence. USA: Oxford University Press.

Silva, J. S., \& Tenreyro, S. (2006). The Log of Gravity. Review of Economics and Statistics , 88 (4), 641-658.

Soloaga, I., \& Winters, L. A. (2001). How Has Regionalism in the 1990s Affected Trade? North American Journal of Economics and Finance, 12, 1-29.

Soloaga, I., \& Winters, L. A. (2001). Regionalism in The Nineties: What Effect on Trade? The North American Journal of Economics and Finance, 12, 1-29.

Tang, D. (2005). Effects of the Regional Trading Arrangements on Trade: Evidence from the NAFTA, ANZCER and ASEAN Countries, 1989-2000. Journal of Trade and Economic Development, 14 (2), 241-265.

The World Bank . (2001). Global Economic Prospects and the Developing Countries 2002: Making Trade Work for the Poor. Washington, D.C.

The World Bank. (2004). Trade Policies in South Asia: An Overview (In Three Volumes) Volume ll: An Overview. Washington, D.C.: The World Bank.

Trotignon, J. (2010). Does Regional Integration Promote the Mulitilateralization of Trade Flows? A Gravity Model Using Panel Data. Journal of Economic Integration, 25 (2), 223-251.

Schott, J. (ed.), 2004. Free Trade Agreements: US Strategies and Priorities, Washington, D.C.:Peterson Institute Press.

Tumbarello, P. (2007, March). Are Regional Trade Agreements in Asia Stumbling or Building Blocks? Implications for the Mekong-3 Countries. IMF Working Paper.

Viner, J. (1950). The Customs Union Issue. New York: Carnegie Endowment for International Peace.

WTO. (2010). International Trade Statistics 2010. World Trade Organization.

WTO. (2004). World Trade Report 2004 Exploring the linkage between the domestic policy environment and international trade. 


\section{Appendices}

Table A1. Membership of 12 Developing RTAs

\begin{tabular}{|c|c|c|}
\hline $\begin{array}{c}\text { AFTA } \\
\text { (ASEAN Free Trade Agreement) }\end{array}$ & $\begin{array}{c}\text { ANDEAN } \\
\text { (Andean Community) }\end{array}$ & $\begin{array}{c}\text { CEMAC } \\
\text { (Economic and Monetary } \\
\text { Community of Central Africa) } \\
\end{array}$ \\
\hline $\begin{array}{l}\text { Brunei Draussalam (1992) } \\
\text { Indonesia (1992) } \\
\text { Malaysia (1992) } \\
\text { Philippines (1992) } \\
\text { Singapore (1992) } \\
\text { Thailand (1992) } \\
\text { Vietnam (1995) } \\
\text { Laos (1997) } \\
\text { Myanmar (1997) } \\
\text { Cambodia (1999) }\end{array}$ & $\begin{array}{l}\text { Bolivia (1988) } \\
\text { Columbia (1988) } \\
\text { Ecuador (1988) } \\
\text { Peru (1988) } \\
\text { Venezuela (1988) }\end{array}$ & $\begin{array}{l}\text { Cameroon (1999) } \\
\text { Central of African Rep. (1999) } \\
\text { Chad (1999) } \\
\text { Congo, Republic of (1999) } \\
\text { Equatorial Guinea (1999) } \\
\text { Gabon (1999) }\end{array}$ \\
\hline $\begin{array}{c}\text { CIS } \\
\text { (Commonwealth of Independent States) }\end{array}$ & $\begin{array}{c}\text { EAC } \\
\text { (East African Community) }\end{array}$ & $\begin{array}{c}\text { ECOWAS } \\
\text { (Economic Community of West Africa) }\end{array}$ \\
\hline $\begin{array}{l}\text { Armenia (1995) } \\
\text { Azerbaijan (1995) } \\
\text { Belarus (1995) } \\
\text { Georgia (1995) } \\
\text { Kazakhstan (1995) } \\
\text { Kyrgyz Republic (1995) } \\
\text { Moldova (1995) } \\
\text { Russia (1995) } \\
\text { Tajikistan (1995) } \\
\text { Ukraine (1995) } \\
\text { Uzbekistan (1995) }\end{array}$ & $\begin{array}{l}\text { Burundi (2000) } \\
\text { Kenya (2000) } \\
\text { Rwanda (2000) } \\
\text { Tanzania (2000) } \\
\text { Uganda (2000) }\end{array}$ & $\begin{array}{l}\text { Benin (1993) } \\
\text { Burkina Faso (1993) } \\
\text { Cape Verde (1993) } \\
\text { Côte d'Ivoire (1993) } \\
\text { Gambia (1993) } \\
\text { Ghana (1993) } \\
\text { Guinea (1993) } \\
\text { Guinea-Bissau (1993) } \\
\text { Liberia (1993) } \\
\text { Mali (1993) } \\
\text { Niger (1993) } \\
\text { Nigeria (1993) } \\
\text { Senegal (1993) } \\
\text { Sierra Leone (1993) } \\
\text { Togo (1993) }\end{array}$ \\
\hline
\end{tabular}

(Source) World Trade Organization 
Table A1. Membership of 12 Developing RTAs

(Continued)

\begin{tabular}{|c|c|c|}
\hline $\begin{array}{c}\text { GCC } \\
\text { (Gulf Cooperation Council) }\end{array}$ & $\begin{array}{c}\text { MERCOSUR } \\
\text { (Southern Common Market) }\end{array}$ & $\begin{array}{c}\text { PAFTA } \\
\text { (Pan-Arab Free Trade Area) }\end{array}$ \\
\hline $\begin{array}{l}\text { Bahrain (2003) } \\
\text { Kuwait (2003) } \\
\text { Oman (2003) } \\
\text { Qatar (2003) } \\
\text { Saudi Arabia (2003) } \\
\text { United Arab Emirates (2003) }\end{array}$ & $\begin{array}{l}\text { Argentina (1991) (Dummy 1992) } \\
\text { Brazil (1991) } \\
\text { Paraguay (1991) } \\
\text { Uruguay (1991) }\end{array}$ & $\begin{array}{l}\text { Algeria (1998) } \\
\text { Bahrain (1998) } \\
\text { Egypt (1998) } \\
\text { Iraq (1998) } \\
\text { Jordan (1998) } \\
\text { Kuwait (1998) } \\
\text { Lebanon (1998) } \\
\text { Libya (1998) } \\
\text { Morocco (1998) } \\
\text { Oman (1998) } \\
\text { Qatar (1998) } \\
\text { Saudi Arabia ( 1998) } \\
\text { Syrian Arab Republic (1998) } \\
\text { Tunisia (1998) } \\
\text { United Arab Emirates (1998) }\end{array}$ \\
\hline $\begin{array}{c}\text { SADC } \\
\text { (Southern Africa Development } \\
\text { Community) }\end{array}$ & $\begin{array}{c}\text { SAPTA } \\
\text { (Southern Asian Preferential } \\
\text { Trade Agreement) }\end{array}$ & $\begin{array}{c}\text { WAEMU } \\
\text { (West Africa Economic } \\
\text { and Monetary Union) }\end{array}$ \\
\hline $\begin{array}{l}\text { Angola (2000) (Dummy 2001) } \\
\text { Botswana (2000) } \\
\text { Congo, Dem.Rep.of (2000) } \\
\text { Lesotho (2000) } \\
\text { Madagascar (2004) } \\
\text { Malawi (2000) } \\
\text { Mauritius (2000) } \\
\text { Mozambique (2000) } \\
\text { Seychelles (2001-2004, 2008) } \\
\text { South Africa (2000) } \\
\text { Swaziland (2000) } \\
\text { Tanzania (2000) } \\
\text { Zambia (2000) } \\
\text { Zimbabwe (2000) }\end{array}$ & $\begin{array}{l}\text { Bangladesh (1995) (Dummy 1996) } \\
\text { Bhutan (1995) } \\
\text { India (1995) } \\
\text { Maldives (1995) } \\
\text { Nepal (1995) } \\
\text { Pakistan (1995) } \\
\text { Sri Lanka (1995) }\end{array}$ & $\begin{array}{l}\text { Benin (2000) } \\
\text { Burkina Faso (2000) } \\
\text { Côte d'Ivoire (2000) } \\
\text { Guinea - Bissau (2000) } \\
\text { Mali (2000) } \\
\text { Niger (2000) } \\
\text { Senegal (2000) } \\
\text { Togo (2000) }\end{array}$ \\
\hline
\end{tabular}

(Source) World Trade Organization 